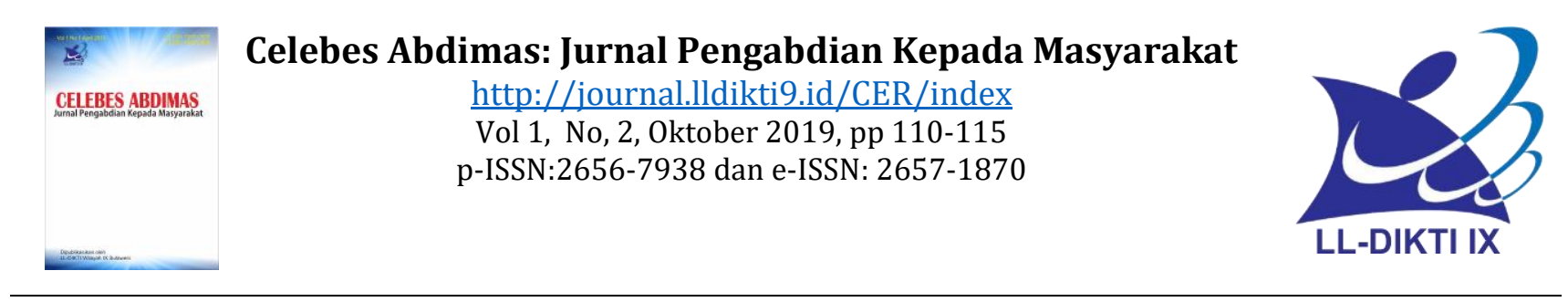

\title{
Pendampingan Guru-Guru SMPN 49 Dan 53 Kota Makassar Dalam Pengembangan Perangkat Pembelajaran Abad 21 Untuk Meningkatkan Kompotensi Guru
}

\author{
Munirah', Nurlina Subair ${ }^{2}$ \\ Pendidikan Bahasa dan Sastra Indonesia, Universitas Muhammadiyah Makassar. \\ Email: munirah@unismuh.ac.id
}

\section{Artikel info}

Artikel history:

Received;Agustus-2019

Revised: September-2019

Accepted;Oktober-2019

Publish: Oktober-2019
Abstract. This service aims to solve partner problems (teachers of 49 and 53 Junior High School Makassar City), namely developing 21st century learning tools to increase teacher pedagogical potential. The form of this service is training with direct assistance. Output targets in training activities are (1) Increasing teacher knowledge in developing 21st century-based learning tools, namely learning implementation plans (lesson plans), worksheets, and assessment instruments; (2) Increase teacher knowledge in developing teacher competency. Output targets in mentoring activities are to produce products in the form of learning tools based on 21st century learning including Product Learning Implementation Plan (RPP), Student Worksheet Products, and Product Assessment Instruments. The dedication method used to achieve the goal (output) is by adopting a mechanism for implementing action research which consists of 4 (four) stages, namely: planning, action, observation-evaluation, and reflection. The planning stage is the preparation stage, the action stage is the core stage (the realization of the IbM in the form of training and mentoring, the observation and evaluation stage is the stage of measuring the success of the program, while the reflection stage is the policy making stage (strategic step) in continuing the program to improve things that have been done before The results of the teacher training assistance at 49 and 53 Junior High School Makassar City are categorized as successful and very active in developing 21st century based learning tools.

Abstrak. Pengabdian ini bertujuan untuk menyelesaikan permasalahan mitra (guru-guru SMP Negeri 49 dan 53 Kota Makassar) yaitu mengembangan perangkat pembelajaran abad 21 untuk meningkatkan kompotensi pedagogi Guru. Bentuk kegiatan pengabdian ini yaitu pelatihan dengan pendampingan secara langsung. Target luaran dalam kegiatan pelatihan yaitu (1) Meningkatkan pengetahuan guru dalam mengembangkan perangkat pembelajaran berbasis abad 21 yaitu rencana pelaksanaan pembelajaran (RPP), LKS, dan instrument penilaian; (2) Meningkatkan pengetahuan guru dalam mengembangkan 
kompotensi guru. Target luaran dalam kegiatan pendampingan yaitu menghasilkan produk berupa perangkat pembelajaran berbasis pembeljaran abad 21 meliputi Produk Rencana Pelaksanaan Pembelajaran (RPP), Produk Lembar Kerja Siswa, dan Produk Instrument Penilaian. Metode pengabdian yang digunakan untuk mencapai tujuan (luaran) yaitu dengan mengadopsi mekanisme pelaksanaan action research yang terdiri dari 4 (empat) tahapan, yaitu: perencanaan, tindakan, observasievaluasi, dan refleksi. Tahap perencanaan merupakan tahap persiapan, tahap tindakan merupakan tahap inti (realisasi IbM berupa pelatihan dan pendampingan, tahap observasi dan evaluasi adalah tahap mengukur keberhasilan program, sedangkan tahap refleksi yaitu tahap pengambilan kebijakan (langkah strategis) dalam melanjutkan program untuk perbaikan hal yang telah dikerjakan sebelumnya. Hasil pendampingan pelatihan guru SMPN 49 dan 53 Kota Makassar dikategorikan berhasil dengan baik dan sangat aktif dalam menyusun perangkat pembelajaran berbasis abad 21 .

Keywords:

21st Century

Learning Tools;

pedagogical

potential;
Coresponden author:

Email: ajeng_ners@yahoo.com

artikel dengan akses terbuka dibawah lisensi CC BY -4.0

\section{PENDAHULUAN}

Makassar adalah Ibu Kota Provinsi Sulawesi Selatan, yang terletak di bagian Selatan Pulau Sulawesi yang dahulu disebut Ujung Pandang, terletak antara 119²4'17'38” Bujur Timur dan 58'6'19" Lintang Selatan yang berbatasan sebelah Utara dengan Kabupaten Maros, sebelah Timur Kabupaten Maros, sebelah selatan Kabupaten Gowa dan sebelah Barat adalah Selat Makassar. Kota Makassar memiliki topografi dengan kemiringan lahan $0-2^{\circ}$ (datar) dan kemiringan lahan $3-15^{\circ}$ (bergelombang). Luas Wilayah Kota Makassar tercatat $175,77 \mathrm{~km}$ persegi. Kota Makassar memiliki kondisi iklim sedang hingga tropis memiliki suhu udara ratarata berkisar antara $26,{ }^{\circ} \mathrm{C}$ sampai dengan $29^{\circ} \mathrm{C}$.

Kota Makassar adalah kota yang terletak dekat dengan pantai yang membentang sepanjang koridor barat dan utara dan juga dikenal sebagai "Waterfront City" yang didalamnya mengalir beberapa sungai (Sungai Tallo, Sungai Jeneberang, dan Sungai Pampang) yang kesemuanya bermuara ke dalam kota. Kota Makassar merupakan hamparan daratan rendah yang berada pada ketinggian antara 0-25 meter dari permukaan laut. Dari kondisi ini menyebabkan Kota Makassar sering mengalami genangan air pada musim hujan, terutama pada saat turun hujan bersamaan dengan naiknya air pasang.

Secara administrasi Kota Makassar dibagi menjadi 15 kecamatan dengan 153 kelurahan. Di antara 15 kecamatan tersebut, ada tujuh kecamatan yang berbatasan dengan pantai yaitu Kecamatan Tamalate, Kecamatan Mariso, Kecamatan Wajo, Kecamatan Ujung Tanah, Kecamatan Tallo, Kecamatan Tamalanrea, dan Kecamatan Biringkanaya

Berdasarkan data Dinas Pendidikan, bertambahnya sepuluh sekolah berarti kini ada total 55 SMP Negeri di Makassar. Ditambah 162 sekolah swasta, maka ada 217 SMP dan sederajat. Pemerintah Kota Makassar berupaya untuk meningkatkan dan memepertahankan kinetja organisasi Dinas Pendidikan Kota Makassar dalam menghadapi perkembangan perubahan lingkungan srategis yang sangat dinamis serta factor-faktor kunci yang berubah dengan cepat dan sering tidak terduga. Sehubungan dengan itu, pengembangan pendidikan di Kota Makassar membutuhkan berbagai perencanaan yang tepat sehingga mampu menghasilkan model perencanaan strategis yang intinya mengacu pada Visi, Misi dan berbasis pada analis 
lingkungan strategis. Rencana Strategis Dinas Pendidikan Kota Makassar ini diharapkan: Dapat memfasilitasi komunikasi dan partisipasi serta mengakomodasi berbagai kepentingan yang berbeda dan sekaligus dapat membantu pembuatan keputusan secara tertib maupun keberhasilan implementasi kegiatan, dapat dijadikan sebagai pedoman dalam melakukan tindakan sekaligus sebagai evaluasi atas kinerja yang dicapai dan menjadi Pedoman dalam perencanaan, pelaksanaan, evaluasi dan pengawasan atas kinerja yang dapat dicapai.

Sasaran penyelenggaraan pendidikan dan kebudayaan di Kota Makassar melalui penyediaan deposito pendidikan gratis. Deposito pendidikan Gratis yang dimaksudkan untuk member kesempatan yang seluas-luasnya bagi semua masyarakat dan lebih khusus kepada golongan masyarakat tidak mampu di kota Makassar untuk menikmati pendididkan yang berkualitas tanpa membedakan ras, suku dan agama. Berikut ini adalah sasaran penyelenggara pendidikan dan kebudayaan di Kota Makassar tahun 2014-2019.

Kebijakan pemerintah Kota ini harus dibarengi dengan kesiapan guru-guru dalam merancang pendidikan berbasis pembelajaran abad 21. Bagi guru-guru di Kota Makassar, pendidikan berbasis pembelajaran abad 21 adalah sesuatu yang baru dilevel SMP. Berdasarkan hasil wawancara (4 April 2019) dengan kepala SMPN 49 dan 53 Makassar bahwa guru-guru mereka masih tampak kebigungan dalam merancang perangkat pembelajaran berbasis pembelajaran abad 21. Umumnya mereka membuat perangkat pembelajaran seperti konten perangkat pembelajaran pada umumnya. Pengakuan serupa diutarakan oleh kepala SMPN di Kota Makassar. Beberapa sekolah yang diwawancarai adalah sekolah unggulan (representasi SMP di Kota Makassar). Secara spesifik, perangkat pembejaran yang dimaksud yaitu meliputi Alokasi Waktu, Standar Isi, Silabus, Rencana Pelaksanaan Pembelajaran (RPP), LKS, dan Instrument Penilaian (pengakuan Kepala SMPN 49 dan 53 Makassar). Kepala SMP Neg. 49 dan 53 Makassar menambahkan, bahwa selain ketidakpahaman guru-guru dalam membuat perangkat pembelajaran, guru-guru juga belum mampu menyusun bahan ajar berbasis pembelajaran abad 21 sebagai salah satu kebutuhan utama dalam proses belajar mengajar (PBM). Selama ini, guru-guru memakai bahan ajar visual (buku teks) yang dibeli dari penerbit. Tetapi buku-buku tersebut sudah tidak bisa digunakan karena tidak berbasis pembelajaran abad 21.

\section{Metode}

Rancangan mekanisme pelaksanaan kegiatan IbM ini dilakukan dengan mengadopsi langkah-langkah action research yang terdiri dari 4 (empat) tahapan, yaitu: perencanaan, tindakan, observasi-evaluasi, dan refleksi.

\section{Perencanaan}

Kegiatan-kegiatan yang dilakukan pada tahap perencanaan adalah:

a. Rapat pemantapan Tim Hibah

Tim pelaksana diundang untuk mengadakan pertemuan persiapan pelaksanaan dengan melibatkan LP3M Unismuh. Tim pelaksana kemudian diberikan pembekalan mengenai maksud, tujuan, rancangan mekanisme program IbM dan beberapa hal teknis berkaitan dengan metode/teknik pelaksanaan.

b. Sosialisasi program IbM pada dua sekolah mitra (khalayak sasaran)

Sosialisasi dilakukan dalam bentuk koordinasi dengan mengundang semua guru, Kepala Sekolah, dan UPTD Dinas Pendidikan Pemuda dan Olah Raga Kecamatan Kajang yang berkenaan dengan program yang akan dilaksanakan. Kegiatan sosialisasi dilakukan oleh Tim Pelaksana IbM didampingi oleh LP3M Unismuh.

c. Penyusunan program pelatihan

Berdasarkan hasil identifikasi, hasil analisis permasalahan yang ada, hasil analisis kebutuhan, dan hasil analisis potensi sekolah, selanjutnya disusun rangkaian program pelatihan. 
113 Celebes Abdimas: Jurnal Pengabdian Kepada Masyarakat

\section{Tindakan}

Tindakan dalam kegiatan ini berupa implementasi Program. Kegiatan-kegiatan yang dilakukan dalam implementasi program pelaksanaan pelatihan dan pendampingan secara langsung kepada guru-guru. Secara spesifik, kegiatan pelatihan dan pendampingan yang akan dilaksanakan yaitu:

a. Program pelatihan dan pendampingan pengembangkan perangkat pembelajaran, berbasis pembelajaran abad 21 meliputi:

1) Alokasi Waktu

2) Pemetaan Isi

3) Silabus Pembelajaran

4) Rencana Pelaksanaan Pembelajaran (RPP)

5) Lembar Kerja Siswa

6) dan Instrument Penilaian

\section{Observasi dan Evaluasi}

Observasi dan evaluasi dilakukan terhadap proses dan hasil pengembangan perangkat pembelajaran dan bahan ajar berbasis pembelajaran abad 21 yang telah dibuat oleh para guru mitra. Instrumen yang digunakan untuk menilai (evaluasi) yaitu:

Tabel 1.Pedoman Evaluasi

\begin{tabular}{|l|c|c|l|}
\hline No. & Rentangan & Nilai & \multicolumn{1}{|c|}{$\begin{array}{c}\text { Katagori } \\
\text { Tingkat PenguasaanKeterampilan }\end{array}$} \\
\hline 1. & $85-100$ & 4 & Berhasil dengan sangat baik \\
\hline 2. & $70-84$ & 3 & Berhasil dengan baik \\
\hline 3. & $55-69$ & 2 & Cukup berhasil \\
\hline 4. & $<54$ & 1 & Kurang berhasil \\
\hline
\end{tabular}

Beberapa hal yang diobservasi dalam proses realisasi yaitu kendala-kendala, kekurangan-kekurangan, dan kelemahan-kelemahan yang muncul dalam proses pembuatan pelatihan dan pendampingan.

\section{Refleksi}

Refleksi dilakukan terhadap kegiatan yang telah dilaksanakan. Hal ini dilakukan sematamata untuk mengetahui kekurangan-kekurangan atau kelebihan-kelebihan terhadap kegiatankegiatan yang telah dilakukan dalam rangka untuk menetapkan rekomendasi terhadap keberlangsungan atau pengembangan kegiatan-kegiatan selanjutnya.

\section{Partisipasi Mitra}

Mitra dalam hal ini berpartisipasi sebagai objek utama dalam kegiatan IbM. Mitra utama dalam kegiatan ini yaitu SMP Neg. 49 dan 53 Makassar. Segala bentuk sarana dan prasarana yang dibutuhakn di lokasi IbM akan difasilitasi secara maksimal oleh kedua mitra sekolah. Mitra juga akan berfungsi sebagai panitia lokal dalam menyukseskan kegiatan IbM, seperti pemasangan spanduk, penyebaran undangan kegiatan IbM ke sekolah lain. Dengan kata lain, mitra akan membantu kegiatan tekniks IbM yang sifatnya lokal yang tidak dapat dijangkau oleh tim utama IbM karena permasalahan jarak dan waktu.

\section{Hasil Dan Pembahasan}

Hasil kegiatan pengabdian masyarakat secara garis besar mencakup beberapa komponen sebagai berikut: 1) Keberhasilan target jumlah peserta pelatihan; 2) Ketercapaian tujuan pelatihan; 3) Ketercapaian target materi yang telah direncanakan; dan 4) Kemampuan peserta dalam menyusun silabus dan perangkat pembelajaran. 
Target peserta pendampingan seperti direncanakan sebelumnya kurang lebih 30 orang guru. Dalam pelaksanaanya, kegiatan ini diikuti oleh 30 orang peserta. Dengan demikian dapat dikatakan bahwa target peserta tercapai $100 \%$. Angka tersebut menunjukkan bahwa kegiatan pengabdian dilihat dari jumlah peserta yang mengikuti pendampingan dalam penyusunan perangkat pembelajaran abad 21 berhasil dengan baik dan sangat aktif.

Ketercapaian tujuan pendampingan peningkatan menyusun perangkat pembelajaran sangat aktif, namun keterbatasan waktu yang disediakan mengakibatkan tidak semua materi dapat disampaikan dan dilakukan di lapangan. Namun dilihat dari hasil latihan para guru, yaitu kualitas perangkat pembelajaran (RPP) telah dibuat dengan baik, maka dapat disampaikan bahwa tujuan kegiatan ini dapat tercapai.

Ketercapaian target materi pada kegiatan pengabdian dikategorkan baik, karena materi pendampingan telah dapat disampaikan secara keseluruhan walaupun perangkat pembelajaran (RPP) belum divalidasi. Materi pendampingan yang telah disampaikan sebagai berikut: 1) Pengantar oleh kepala sekolah SMPN 49 dan 53 Kota Makassar. 2) Pemateri I (Penyusunan perangkat RPP, Pemateri 2 membawakan materi penyusunan bahan ajar/LKPD dan penilaian. 2) Tata cara penyusunan perangkat pembelajaran; 3) Prosedur dan format penyusunan perangkat pembelajaran abad 21.4) Praktik penyusunan perangkat pembelajaran, dan 5) Pendampingan peserta dalam menyusun perangkat pembelajaran.

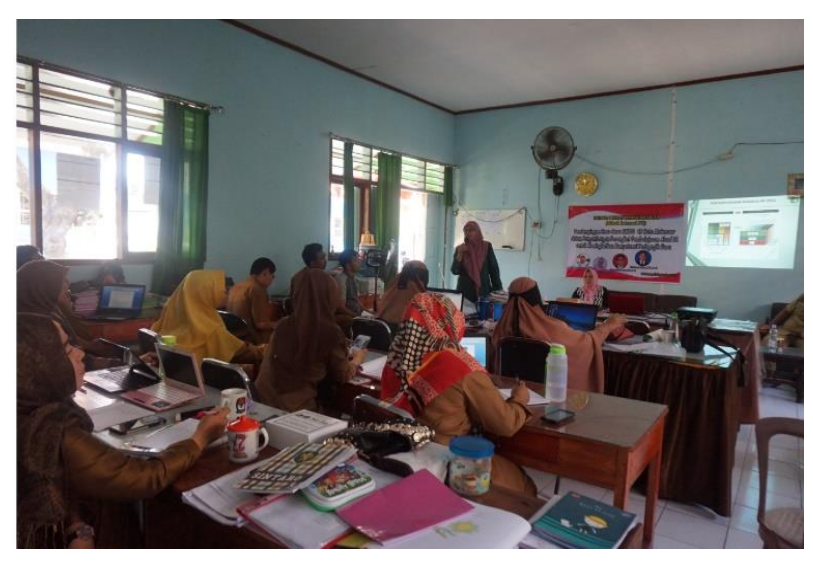

Gambar 1. Pemateri pelatihan guru SMPN 49 Makassar

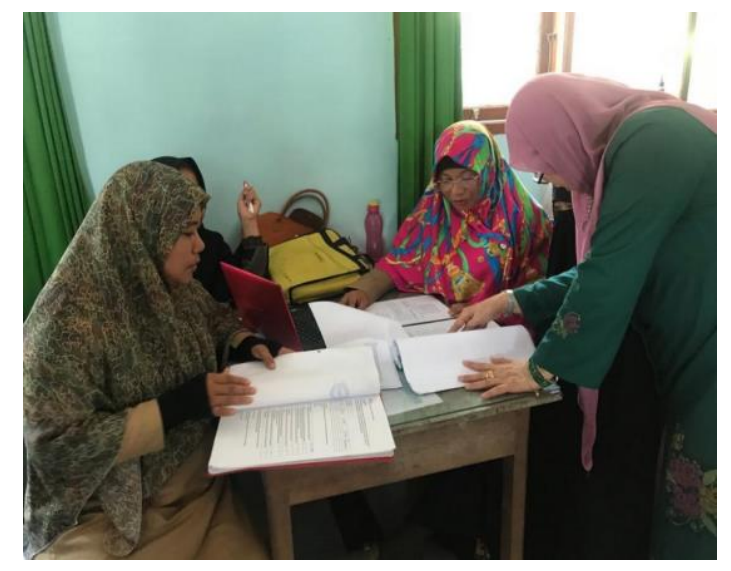

Gambar 2. Pemateri pelatihan guru SMPN 53 Makassar
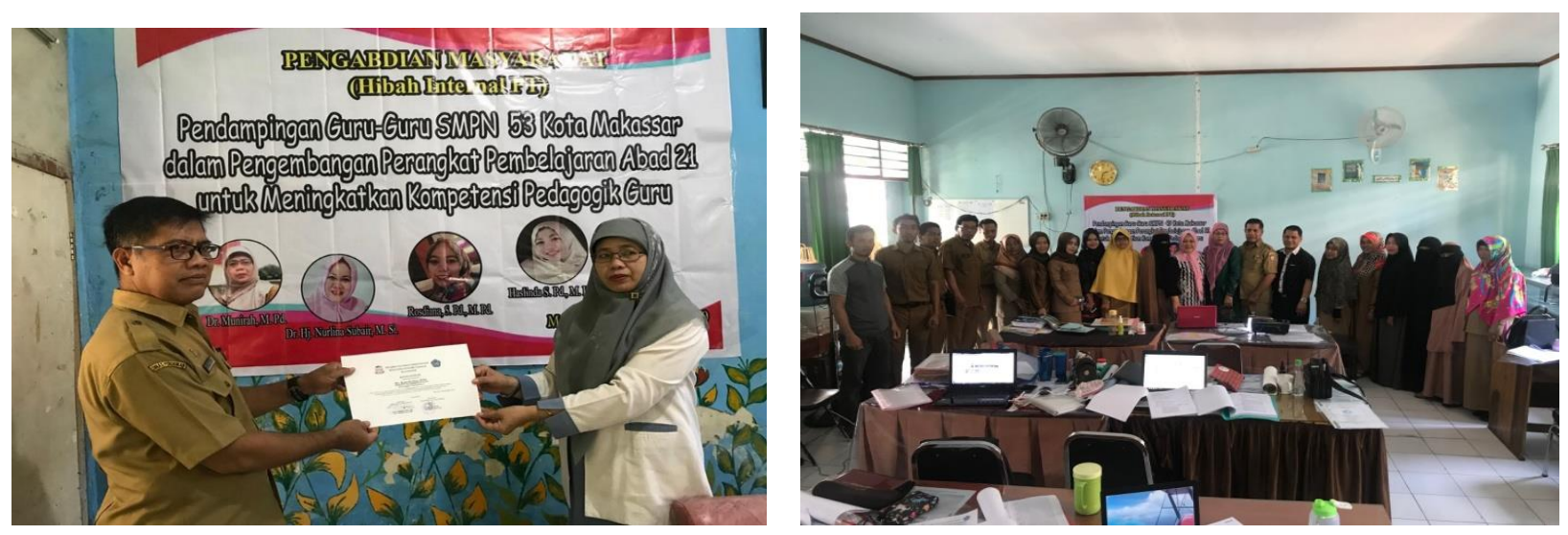

Gambar 3. Penyerahan sertifikat dan Foto Bersama Peserta dengantim PKM

Kemampuan peserta dilihat dari penguasaan materi masih kurang dikarenakan waktu yang singkat dalam penyampaian materi dan kemampuan para peserta yang berbeda-beda terkait pengalaman guru dan keterlibatan dalam pelatihan sebelumnya. Hal ini disebabkan jumlah materi yang banyak hanya disampaikan dalam waktu dua hari sehingga tidak cukup waktu bagi para peserta untuk memahami dan mempraktikkan secara optimal. 
115 Celebes Abdimas: Jurnal Pengabdian Kepada Masyarakat

Secara keseluruhan kegiatan pendampingan penyusunan perangkat pembelajaran pada mapel Bahasa Indonesia, Matematika, PKn, dan Pendidikan Agama mendapatkan nilai yang baik. Keberhasilan ini selain diukur dari ketepatan dalam menyusun komponen Perangkat pembelajaran, juga dapat dilihat dari kepuasaan dan keaktifan guru-guru yng sangat aktif setelah mengikuti kegiatan. Manfaat yang diperoleh guru yakni, guru dapat menyusun RPP, BahanAjar/LKPD, dan Instrumen penilaian berbasis pembelajaran abad 21 yang diharapkan mengikuti standar untuk dapat dipakai sebagai contoh lebih lanjut untuk dikembangkan di sekolah..

\section{Simpulan Dan Saran}

Berdasarkan hasil kegiatan pendampingan pelatihan guru SMPN 49 dan 53 kota Makassar , maka disimpulkan sebagai berikut;

(1) Kegiatan pengabdian masyarakat menghasilkan perangkat pembelajaran RPP, LKPD, dan Intrumen penilaian berbasis pembelajaran abad 21;

2) Ketercapaian tujuan pelatihan dengan meningkatkan kompetensi pedagogic guru;

3) Ketercapaian target materi yang telah direncanakan;

4) Kemampuan guru-guru dalam menyusun perangkat pembelajaran abad 21.

(5) Terciptanya antusias guru-guru dalam merespon materi perangkat pembelajaran abad 21; dan

(5) Keaktifan Guru SMPN 49 dan 53 Kota Makassar yang sangat aktif.

\section{Ucapan Terima Kasih}

Ucapan terima kasih kepada Rektor Unismuh Makassar yang telah memberikan Hibah Internal pengabdian kepada Masyarakat. Selanjutnya, ucapan terima kasih kepada Ketua Lembaga Penelitian dan Pengabdian Masyarakat Unismuh Makassar dan Kepala Sekolah SMPN 49 dan 53 yang memfasilitasi terlaksananya kegiatan pengabdian masyarakat di Kota Makassar.

\section{Daftar Rujukan}

Endraswara, Swandi. 2011. Metodologi Penelitian Sastra. Jakarta: PT Buku Seru.

Peraturan Pemerintah No.22 tahun 2006 tentang standar proses pembelajaran.

Purwono, Joni, dkk.. 2014. Penggunaan Media Audio-Visual pada Mata Pelajaran Ilmu Pengetahuan Alam di Sekolah Menengah Pertama Negeri 1 Pacitan. Jurnal Teknologi Pendidikan dan Pembelajaran (UNS). Vol.2, No.2. Hal 127 - 144.

Rukli, Munirah. 2018. Pendampingan Pembuatan Soal Ujian Kredibel bagi Guru Madrasah di Kabupaten Soppeng. Jurnal Dedikasi, Vol.20 No.1, Hal.39.

Sanjaya, Wina. 2010. Strategi Pembelajaran Berorientasi Standar Proses Pendidikan. Jakarta: Kencana.

Susanto, Irwan Kristono. 2011. Pengantar Metodologi Penelitian di Perguruan Tinggi. Yogyakarta: Puji Permai.

UNESCO. (1991). Values and Ethics and the Science and Technology Curriculum. Bangkok: Principal Regional Office for Asia and the Pasific.

Tim Konsorseum PPG. 2018. Pembelajaran abad 21. Modul PPG. Jakarta: GTK. 